\title{
Concerning the relevance of ISO 14001 adoption in enterprises
}

\section{Marina Lagunova}

Senior lecturer of the "Linguistics" department Mytishchi branch of Bauman Moscow State Technical University, Mytishchi

\begin{abstract}
The paper justifies the relevance of adopting an international standard of environmental management system ISO 14001 in Russian enterprises. The diffusion of the ISO certificates is viewed; the example of environmental management at a Russian enterprise is given. It is underlined that exporting enterprises gain a competitive advantage by adopting the standard.
\end{abstract}

Keywords: environmental management system, enterprise, ISO, manufacturing process management.

\section{Introduction}

In September 2015, Member States of the United Nations adopted the 2030 Agenda for Sustainable Development, setting 17 goals. Among these goals, accepted for implementation by the Russian Federation there is goal No 12- «Responsible consumption and production»; paragraph 6 of this goal encourages «companies, especially large and transnational companies, to adopt sustainable practices and to integrate sustainability information into their reporting cycle». [6]

One of the steps towards greening enterprises is the implementation of environmental management systems (EMS). D. Yu. Dvinin, comparing various definitions of environmental management, deduced a definition that more fully covers the various aspects of this phenomenon. He takes environmental management as «a part of the overall administrative management system that implements a value orientation for achieving sustainable development, which includes an organizational structure, optimal environmental and economic planning, responsibility, methods, procedures, processes and resources necessary for development, implementation, analysis and maintenance of environmental policy» [2, p.22] of an organization.

\section{Methods and materials}

«International Organization for Standardization» (ISO) developed a series of environmental management standards ISO 14000, a fundamental of which - ISO 14001 updated in 2015. Familiarization with the standard is paid, the certification procedure takes place at the facilities external to ISO. Russia has national GOST R ISO 14001-2016 «Environmental Management Systems - Requirements With Guidance For Use», declared as identical to the international standard, however, Russian companies can also receive an international certificate of compliance with the standard. 
The implementation of the standard in the enterprise's activities involves streamlining the environmental component of the company's activities, building a system for managing the ecological (interacting with the environment) aspects of the activity, and publicly declaring the company's commitment to sustainable development values, which creates a positive image of the company in the eyes of consumers and partners.

The total number of valid international ISO 14001 certificates as of December 31, 2018 amounted to 307059 pieces. According to ISO, the ISO 14001 standard is the second most popular after the ISO 9001 quality management system standard. [3]

It should be noted that since 2018, ISO separately takes account of the certificates in each country and of the number of sites covered by the standard, and whereas until 2018 the data received by ISO was in a mixed form. The site is understood as a permanent location (territory), where a certified organization carries out its activities. [3] Consequently, the number of sites exceeds the number of certificates. Proceeding from the above a direct comparison of the number of valid certificates between 2018 and previous years does not give sufficiently reliable results.

\section{Results}

The number of valid certificates in Russia as of December 31, 2018 is 898, companies conduct certified activities in 1397 sites. Russia ranks 45th among 190 countries in the number of certificates; the absolute leader is China (136715 pc.). Between 1999 and 2017 fluctuations are noted in the number of international certificates received by Russian companies (Fig. 1). However, the adaptation of foreign experience and the tightening of the requirements of international markets will contribute to an increase in the number of certificates in Russia [1].

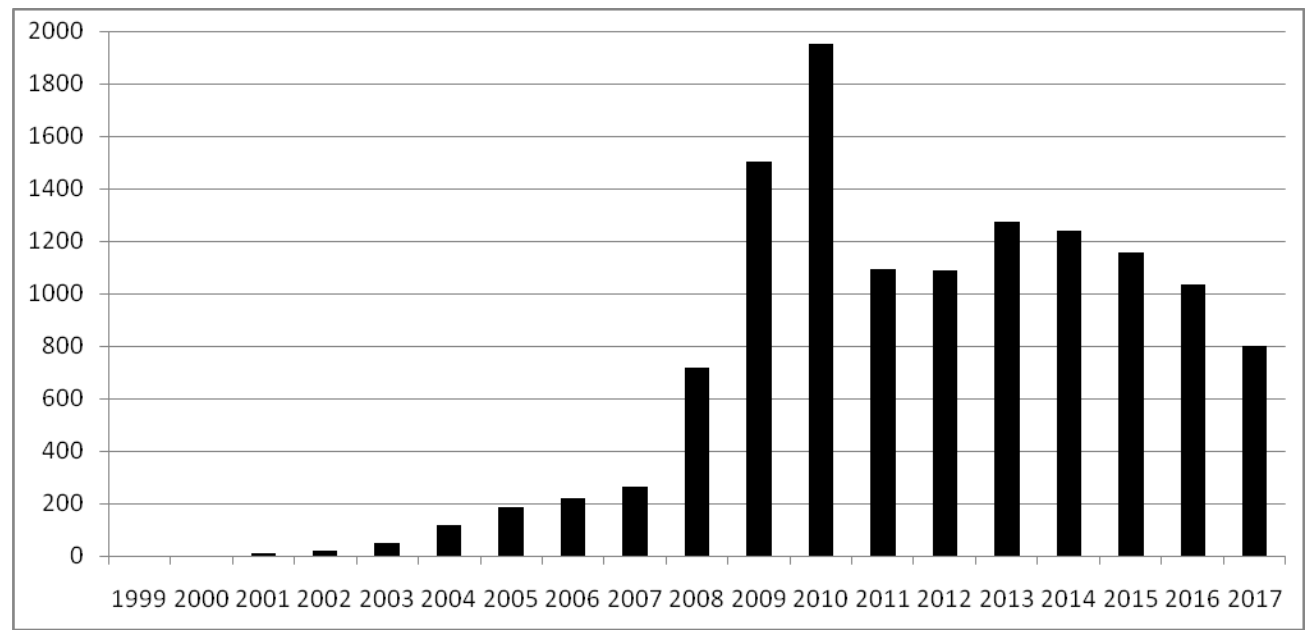

Fig 4. The number of ISO 14001 certificates in Russia by years (from 1990 to 2017, in pieces, compiled by the author according to ISO [3]).

Out of 5722 international certificates operating in the food, beverage and tobacco sectors in the world, $30(0.52 \%)$ were received by Russian companies. One of the food enterprises that introduced the standard is JSC Khlebprom, a manufacturer and exporter of crackers, bakery and flour confectionery.

The company has proclaimed environmental protection as an essential component of corporate social responsibility (Fig. 2). All four production sites of the company are certified 
according to ISO 14001: 2015. For the first time, divisions in Chelyabinsk and Krasnogorsk were certified in 2015, in Noginsk and Smolensk Region - in 2017 (two certificates cover four sites). [5]

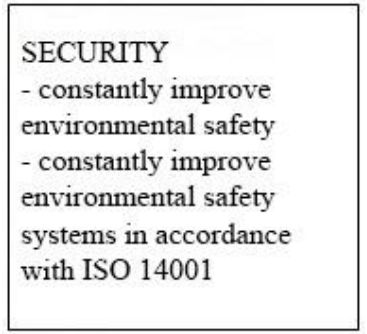

\section{ENVIRONMENTAL} ASPECTS (EA):

- identify EA, evaluate and control them

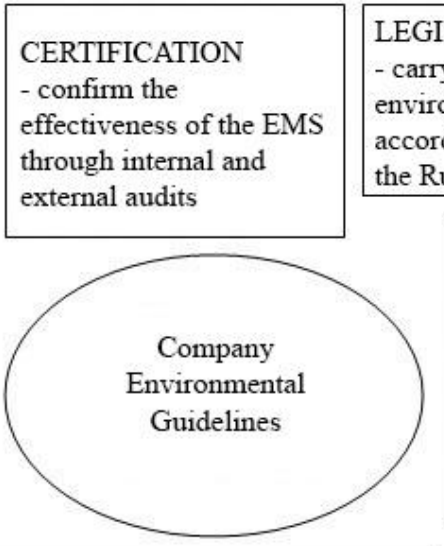

STAFF:

- systematically and purposefully increase the knowledge of employees in the field of environmentally friendly production - involve employees in resolving environmental issues - inform employees about EA and personal responsibilities in the area of environmental protection

\section{LEGISLATION}

- carry out activities in the field of environmental protection in accordance with the legislation of the Russian Federation

\section{PRODUCTION}

- introduce technologies and

equipment that reduce

harmful and dangerous environmental impacts and waste

\section{EXTERNAL}

ENVIRONMENT

- inform contractors and

third parties about EA and

personal responsibilities

in the field of

environmental protection

Fig 2. The environmental component of the policy of JSC Khlebprom (compiled by the author according to the «Policy in the field of labor protection and the environment» [5]).

JSC Khlebprom is a major market participant, exporting products to countries such as the UK, Belgium, Germany, Spain, Poland, Holland, Thailand [5]. The company's net profit in 2016 increased by $215 \%$ compared to 2015 , and in 2017 - by $106 \%$ compared to 2016 [4].

Certification according to the standards of ISO 14000 family is one of the competitive advantages for exporting enterprises, especially when export is directed to developed countries, where requirements are stricter and the level of environmental awareness of consumers is higher. It is noted that more often large enterprises with more experience and resources implement the certification. [7]. V. A. Dadonov calls the creation and certification of integrated management systems at Russian enterprises, including EMS, a prerequisite for promoting their products in international markets, while contributing to the competitiveness of both products and enterprises [1].

\section{Conclusion}

Implementation of the "green» strategy by the exporting company makes it easier to obtain a competitive advantage in terms of product differentiation, and using this advantage helps to improve the financial performance of the exporter [7]. The development of a «green» marketing strategy, the streamlining of work with the environmental aspects of the enterprise's activities, is facilitated by the introduction of international or national standard ISO 14001 (an international certificate is preferable for export). The main thing is that the certificate should be not just another paper, but a guide to action and also the result, which was preceded by the present work on the greening of production, reducing its harmful effects 
on the environment. After such work and certification, the company will be able to use the certificate as one of the evidences that the management is committed to sustainable development and is taking steps to do this.

At present, Russian enterprises are little covered by EMS certification; therefore, it is necessary to convey to them not only environmental, but also economic advantages of environmental management.

\section{References}

1. V. A. Dadonov Issues of the development of integrated management systems at Russian industrial enterprises in the context of promoting products on international markets. Engineering Journal: Science and Innovation, 2013, issue 3. URL: http://engjournal.ru/catalog/indust/hidden/650.html (access date November, 24 2019)

2. D. Yu. Dvinin Clarification of the «environmental management» concept in order to identify it with respect to other forms of environmental management. // Bulletin of Chelyabinsk State University. Chelyabinsk, 2008 - p. 18-23.

3. ISO research // International Organization for Standardization [Electronic resource]. URL: https://www.iso.org/the-iso-survey.html (access date November, 24 2019)

4. JSC Khlebprom: financial statements and financial analysis. // Accounting. Taxes. Audit. [Electronic resource]. URL: https://www.audit-it.ru/buh_otchet/7448027569_oaokhlebprom (access date November, 25 2019)

5. About the company. Company policy. // JSC Khlebprom [Electronic resource]. URL: https://www.hlebprom.ru/o-kompanii/ (access date November, 25 2019)

6. Sustainable Development Agenda. // United Nations [Electronic resource]. URL: https://www.un.org/sustainabledevelopment/ru/about/development-agenda/ (access data November, 19 2019)

7. Leonidou, L.C.,et al. Environmentally friendly export business strategy: Its determinants and effects on competitive advantage and performance. // International Business Review, Vol. 24, Issue 5, 2015. - Pages 798-811 - http://dx.doi.org/10.1016/j.ibusrev.2015.02.001 (access data November, 24 2019) 